\title{
Karakteristik Fisik Edible Film Pati Jagung (Zea mays L) Termodifikasi Kitosan dan Gliserol
}

\section{Physical Characteristics of Edible Film Made from Corn (Zea mays L) Starch Modified with Chitosan and Glycerol}

\author{
Ihlana Nairfana* dan Muhammad Ramdhani \\ Program Studi Teknologi Hasil Pertanian, Fakultas Teknologi Pertanian, Universitas Teknologi \\ Sumbawa, Nusa Tenggara Barat, Indonesia. \\ *corresponding author, email: ihlana.nairfana@uts.ac.id
}

Manuscript received: 03-05-2020. Accepted: 15-06-2021

\begin{abstract}
ABSTRAK
Edible film merupakan lapis tipis yang dapat digunakan sebagai pengganti plastik sintetis maupun digunakan sebagai kemasan primer pada suatu produk. Salah satu bahan yang digunakan pada penelitian ini adalah pati jagung yang disuspensikan dengan kitosan dan plasticizer gliserol sehingga dapat memperbaiki kualitas edible film. Tujuan dari penelitian ini adalah untuk mengetahui karakteristik fisik edible film pati jagung dengan penambahan kitosan dan gliserol yang dimodifikasi. Penelitian ini menggunakan variasi konsentrasi $15 \%, 20 \%$ dan $25 \%$, serta variasi konsentrasi gliserol $30 \%$ dan $40 \%$. Karakteristik fisik edible film yang dilakukan meliputi ketebalan, daya serap, kelarutan dan degradasi. Dari hasil pengujian didapatkan hasil ketebalan berkisaran 0.06-0.14 mm. Daya serap, kelarutan dan degradasi film terbaik terdapat pada penambahan $15 \%$ kitosan dan $40 \%$ gliserol, sedangkan yang terendah terendah terdapat pada penambahan $25 \%$ kitosan dan $30 \%$ gliserol.
\end{abstract}

Kata kunci: plastik; ketebalan; daya serap; kelarutan

\begin{abstract}
Edible film is a thin layer that is used as a substitute for synthetic plastic or used as a primary packaging of food product. Corn starch that is suspended with chitosan and glycerol is able to improve the quality of edible film. The purpose of this research is to determine the physical characteristics of edible film from modified corn starch. The concentrations of chitosan used were $15 \%, 20 \%$ and $25 \%$, and glycerol were $30 \%$ and $40 \%$. Physical characteristics of edible film observed were thickness, absorption, solubility and film degradation. The thickness of the film ranges between $0.06-0.14 \mathrm{~mm}$. The best treatment for film absorption, solubility and degradability is obtained from the addition of $15 \%$ chitosan and $40 \%$ glycerol, whilst the lowest was from $25 \%$ chitosan and $30 \%$ glycerol.
\end{abstract}

Keywords: plastics, thickness, absorption, solubility 


\section{PENDAHULUAN}

Perkembangan teknologi pangan sangat pesat dan sudah menghasilkan berbagai jenis produk yang memiliki karekteristik yang berbeda. Setiap produk pangan membutuhkan kemasan untuk mempertahankan kualitasnya. Pengemas pada umumnya merupakan bahan yang sangat diperlukan untuk mempertahankan masa simpan suatu bahan pangan, karena apabila bahan pangan dibiarkan terbuka maka akan cepat terjadi kerusakan. Umumnya jenis pengemas yang sering digunakan adalah plastik Khotimah dalam Lismawati (2017). Plastik merupakan polimer sintesis yang berasal dari minyak bumi sehingga tidak dapat teruraikan oleh bakteri dan mikroba. Hal ini karena bakteri dan mikroba tidak memiliki enzim yang mampu mendegradasi polimer (Zulferiyenni et. al, 2014). Plastik dapat mencemari tanah, air tanah dan apabila dibakar akan menghasilkan asap beracun seperti dioksin yang dapat memicu kanker dan gangguan saraf (Zulferiyenni et. al, 2014). Plastik mengandung berbagai zat kimia yang sangat berbahaya bagi manusia, sehingga para peneliti berinisiatif untuk menghasilkan plastik yang ramah lingkungan dan mampu mempertahankan bahan makanan agar layak dikonsumsi salah satunya adalah edible film.

Edible film merupakan lapis tipis yang berfungsi untuk melapisi bahan pangan yang terbuat dari bahan alami dan layak untuk dikonsumsi. Dilihat dari segi keamanannya edible film sangat cocok untuk dijadikan kemasan yang ramah lingkungan karena memiliki komposisi yang dapat dengan mudah terdegradasi dan terurai di dalam tanah maupun di dalam air. Edible film biasanya langsung digunakan dan dibentuk diatas permukaan produk. Penggunaan edible film sebagai pengemas memiliki banyak keuntungan dibandingkan pengemas sintetik, antara lain langsung dapat dimakan bersama produk yang dikemas, tidak mencemari lingkungan, memperbaiki sifat organoleptik produk yang dikemas, berfungsi sebagai suplemen gizi, sebagai pembawa flavor, pewarna, zat antimikroba dan antioksidan (Lismawati, 2017). Edible film dapat dibuat dari hidrokoloid yang tersedia di alam bebas contohnya seperti pati. Pati merupakan salah satu polimer yang karakteristiknya menyerupai plastik dan salah satu jenis polisakarida yang tersedia melimpah di alam, bersifat mudah terurai (biodegradable), mudah diperoleh, dan murah. Sifat-sifat pati juga sesuai untuk bahan edible film karena dapat membentuk film yang cukup kuat (Winarti dan Christina, 2012). Pati dapat diperoleh dari tumbuh- tumbuhan, seperti penelitian yang dilakukan oleh Kusumawati et. al. pada tahun 2013 yang berfokus pada jagung sebagai sumber pati untuk penelitiannya, dan terbukti pati jagung dapat dijadikan sebagai bahan baku pembuatan film dengan kualitas baik karena mempunya karakter yang dapat menyusun jumlah padatan atau matriks film yang cukup rapat. Jagung merupakan sumber karbohidrat yang sangat berpotensi untuk dijadikan bahan baku edible film. Pati jagung memiliki kadar amilosa yang cukup tinggi sekitar $25 \%$ sehingga diperkirakan dapat menghasilkan film yang lebih kuat daripada sumber pati yang mengandung lebih sedikit amilosa (Kusumawati, et. al. 2013). Namun edible film yang terbuat dari pati ini memiliki kelemahan yaitu akan bersifat rapuh dan sangat mudah terkoyak, sehingga dibutuhkan bahan lain untuk menghasilkan edible film dengan karakter dan mutu yang baik.

Pada umumnya pembuatan edible film menggunakan polisakarida dengan plasticizer berupa gliserol, dimana gliserol yang digunakan mampu menjadikan edible film menjadi 
lebih fleksibel dan halus. Selain itu, gliserol juga aman untuk dikonsumsi selagi takarannya masih dalam taraf aman yakni $10 \mathrm{mg} / \mathrm{m}^{3}$ berdasarkan data Material Safety Data Sheet (MSDS) (Murni et. al, 2013), seperti penelitian yang dilakukan oleh Lismawati, 2017 yakni pembuatan edible film yang diaplikasikan pada permen jelly yang dikemas menggunakan edible film dari pati kentang dengan penambahan gliserol, dan hasil penelitiannya menunjukan kualitas baik dan panelis banyak yang menyukainya. Namun plasticizer gliserol memiliki sifat hidrofilik yang mana akan sangat rentan terhadap air. Jika tidak ditambahkan zat lain maka film akan memiliki karakteristik yang kurang baik. Hal ini yang mendasari penambahan kitosan sebagai zat yang mampu memperbaiki kekurangan yang dimiliki oleh film ini, karena kitosan memiliki sifat hidrofobik yang tahan terhadap air (Anggraini et. al, 2016). Berdasarkan uraian di atas maka penelitian ini akan berfokus pada pembuatan edible film dari pati jagung dengan modifikasi gliserol dan kitosan. Untuk itu, beberapa uji karakteristik akan dilakukan seperti ketebalan, kelarutan, uji serap air, dan lama degradasi dalam tanah.

\section{BAHAN DAN METODE}

\section{Waktu dan Bahan Penelitian}

Penelitian ini merupakan percobaan ekperimental yang dilakukan di Laboratorium Pangan dan Agroindustri, Fakultas Teknologi Pertanian, Universitas Teknologi Sumbawa, dan dilakukan selama 4 bulan pada September 2020 sampai dengan Januari 2021. Bahan yang digunakan dalam penelitian ini adalah pati jagung (merk Maizena), aquadest $\left(\mathrm{H}_{2} \mathrm{O}\right)$, gliserol $\left(\mathrm{C}_{3} \mathrm{O}_{8} \mathrm{H}_{3}\right)$, kitosan, EM4, dan media tanah

\section{Perlakuan dan Desain Percobaan}

Penambahan konsentrasi gliserol 30\%, 40\%, dan penambahan konsentrasi kitosan 15\%, 20\%, 25\% Setiap perlakuan dilakukan pengulangan analisis sebanyak 3 kali ulangan. Setelah larutan sudah terbentuk menjadi film dilakukan pengujian karakteristik film meliputi ketebalan, kelarutan, uji serap air, dan lama degradasi dalam tanah.

Rancangan Acak Lengkap (RAL) yang disusun dengan 2 faktor dan masing-masing faktor terdiri dari 2 dan 3 level serta masing masing perlakuan dilakukan 3 kali pengulangan analisis, sehingga menghasilkan 18 unit percobaan. Faktor pertama adalah konsentrasi gliserol $(30 \%, 40 \%$ dari berat pati) sedangkan faktor kedua adalah konsentrasi kitosan (15\%, $20 \%$, dan $25 \%$ dari berat pati).

\section{Uji Ketebalan Film}

Pengujian ketebelan ini mengacu pada penelitian sebelumnya yang dilakukan oleh Lismawati (2017). Sampel diukur ketebalannya menggunakan mikrometer sekrup pada 5 titik yang berbeda, hasil pengukuran dirata rata sebagai hasil ketebalan film, ketebalan film diukur menggunakan mikrometer sekrup dengan ketelitian $0.001 \mathrm{~mm}$, dan pengujian ini dilakukan sebanyak 3 kali.

\section{Uji Kelarutan Film}

Pengujian kelarutan ini mengacu pada penelitian sebelumnya yang dilakukan oleh Lismawati (2017). Sampel film dan kertas saring dikeringkan dalam oven pada suhu $105^{\circ} \mathrm{C}$ selama 24 jam. Sampel film dan kertas saring ditimbang secara terpisah. Sampel film yang 
telah dikeringkan direndam menggunakan aquadest $50 \mathrm{ml}$ selama 24 jam, setelah itu dilakukan pengadukan. Sampel film yang telah direndam disaring menggunakan kertas saring, lalu dikeringkan dalam oven dengan suhu $105^{\circ} \mathrm{C}$ selama 24 jam, setelah itu ditimbang sebagai nilai (W2), perlakuan ini dilakukan sebanyak 3 kali. Seteah didapatkan data dari hasil penimbangan, data dihitung menggunkan rumus:

$$
\% \text { Kelarutan }=\frac{\text { Berat Awal Sample-Berat akhir Sampel }}{\text { Berat awal Sampel }} \times 100 \%
$$

\section{Uji Serap Air (Water Uptake) terhadap ketahanan Edible film}

Pengujian Daya Serap ini mengacu pada penelitian sebelumnya yang dilakukan oleh Kasmawati (2018). Memotong edible film ukuran $3 \mathrm{~cm}$ x $3 \mathrm{~cm}$. Menimbang edible film yang akan diuji sebagai berat awal (Wo). Mengisi wadah (gelas kimia) dengan aquadest. Sampel kemudian dimasukkan ke dalam wadah yang bersisi akuades selama 1 menit. Setelah itu, diangkat dari wadah dan dikeringkan (dilap permukaannya). Kemudian ditimbang berat sampel (W). Hal yang sama dilakukan hingga diperoleh berat akhir sampel yang konstan setiap 1 menitnya. Setelah didapatkan data dari hasil penimbangan, data dihitung menggunakan rumus:

$$
\operatorname{Air}(\%)=\frac{\mathrm{W}-\mathrm{Wo}}{\mathrm{Wo}} \times 100 \%
$$

\section{Penguraian (Degradability)}

Pengujian penguraian ini dilakukan guna untuk mengetahui lama biofilm yang berbahan dasar pati jagung dapat terurai oleh mikroba. Pengujian ini dilakukan perendaman pada EM4, film dipotong menjadi ukuran $3 \times 3$, metode ini mengikuti metode yang telah dilakukan oleh Handayani et. al. (2015). Uji penguraian ini akan dilakukan selama 15 hari, dan perhitungan data yang dihasilkan mengikuti metode yang dilakukan oleh Anggarini (2013). Perhitungan yang dilakukan sebagai berikut:

$$
\% \text { Kehilangan Berat }=\frac{\mathrm{w} 0-\mathrm{W} 1}{\mathrm{~W} 0} \times 100 \%
$$

Keterangan: W1 adalah berat sampel sebelum perendaman dan W2 adalah berat sampel setelah perendaman. Selanjutnya dihitung laju degradabilitas dengan perhitungan sebagai berikut:

$$
\text { Degradabilitas }=\frac{\mathrm{W} 0-\mathrm{W} 1 \mathrm{mg}}{15 \text { hari }}
$$

\section{Analisis Data.}

Data yang diperoleh dianalisis dengan menggunakan Analysis of Variant (ANOVA) dan dilanjutkan uji beda nyata (BNT) dengan taraf nyata 5\% $(\alpha=0.05)$ dengan menggunakan perangkat lunak SPSS versi 22. 


\section{HASIL DAN PEMBAHASAN}

A. Keterbalan Film

Pengujian ketebalan edible film dari pati jagung dilakukan dengan metode microcal messmer (ASTM 1983), seperti yang dilakukan dalam penelitian Lismawati (2017), dimana dilakukan pengukuran ketebalan pada lima titik yang berbeda, lalu didapatkan rata-rata hasil pengukuran dari lima titik yang berbeda tersebut. Pengukuran ketebalan ini menggunakan alat mikrometer sekrup. Nilai ketebalan edible film dapat dilihat pada Gambar 1.

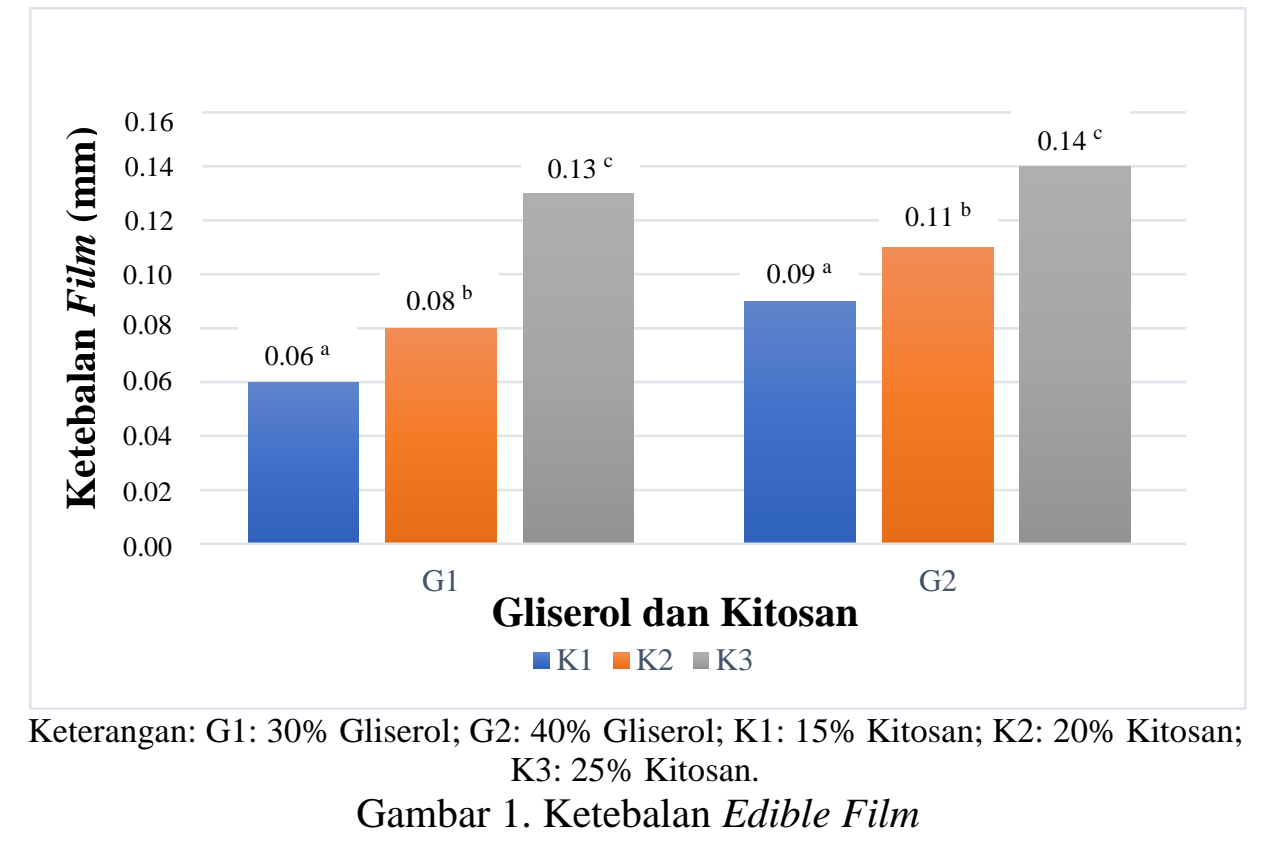

Berdasarkan Gambar 1 didapatkan hasil bahwasanya semakin banyak penambahan konsentrasi gliserol yang ditambahkan maka semakin tebal film yang dihasilkan, terlihat perbedaan pada penambahan 30\% gliserol yang memiliki ketebalan rata-rata $0.06 \mathrm{~mm}$, $0.08 \mathrm{~mm}$, dan $0.13 \mathrm{~mm}$, sedangkan pada penambahan $40 \%$ gliserol memiliki ketebalan yang lebih tinggi. Hal ini terjadi karena semakin tinggi konsentrasi gliserol yang ditambahkan maka total padatan dalam larutan akan semakin meningkat, Ningsih (2015) menyatakan dalam peneltiannya bahwa peningkatan jumlah padatan dalam larutan mengakibatkan polimer-polimer yang menyusun matriks edible film semakin banyak. Selain total padatan dalam larutan, faktor edible film menjadi semakin tebal dipengaruhi oleh viskositas dan kandungan polimer penyusunnya. Fenomena ini juga relevan dengan penelitian yang dilakukan oleh Lismawati (2017) bahwa ketebalan film dari 20\%, 30\% dan $40 \%$ gliserol secara berturut turut mendapatkan hasil ketebalan sebesar $0.058,0.062$ dan 0.071 dalam satuan $\mathrm{mm}$, yang artinya semakin banyak gliserol yang ditambahkan maka ketebalan film akan meningkat. Dilihat dari sifat gliserol yang memiliki tingkat viskositas yang tinggi dibandingkan dengan plasticizer lainnya juga menjadi salah satu indikator mengapa semakin banyak konsentrasi gliserol yang digunakan berpengaruh terhadap ketebalan film (Anggraeni, et. al. 2016). 
Selain gliserol pada penelitian ini juga menggunakan kitosan sebagai bahan yang digunakan untuk pembuatan film, dapat dilihat pada grafik di atas, semakin banyak konsentrasi kitosan yang digunakan maka ketebalan juga semakin meningkat, terlihat pada penambahan $15 \%$ kitosan memiliki ketebalan $0.06 \mathrm{~mm}$ dan $0.09 \mathrm{~mm}$, penambahan $20 \%$ kitosan memiliki ketebalan $0.08 \mathrm{~mm}$ dan $0.11 \mathrm{~mm}$, lalu penambahan $25 \%$ kitosan memiliki ketebalan 0.13 dan 0.14 . Hal ini dapat terjadi karena semakin tinggi konsentrasi kitosan yang digunakan pada pembuatan edible film, maka akan semakin menambah ketebalan pada film yang dihasilkan. Penggunaan konsentrasi kitosan yang jumlahnya semakin banyak akan menghasilkan total padatan pada larutan, sehingga rendemen padatan sebagai bahan pembentuk edible film akan semakin banyak dan menyebabkan ketebalan edible film yang dihasilkan semakin bertambah (Mustapa, et. al. 2017). Hasil ini juga sesuai seperti penelitian Rosalina (2015) tentang pembuatan edible film dari kitosan dengan penambahan pati ubi kayu yang mendapatkan hasil ketebalan yang semakin meningkat seiring meningkatnya konsentrasi kitosan yang ditambahkan.

Skurtys et. al. (2009) menyatakan edible film dapat dikatakan memenuhi syarat bahan pengemas apabila memiliki ketebalan $<0.25 \mathrm{~mm}$. Syarat ketebalan ini juga dikeluarkan oleh Japanese Industrial Standart yang menyatakan standar maksimal ketebalan suatu edible film adalah $0.25 \mathrm{~mm}$. Sedangkan jika suatu edible film akan digunakan sebagai edible coating dengan ketebalan > $0.25 \mathrm{~mm}$ dapat mempengaruhi pertukaran gas hasil respirasi sehingga menyebabkan produk cepat rusak (Lismawati, 2017). Edible film pada penelitian ini berkisar 0.06-0.14 mm dan telah memenuhi standar edible film pada umumnya. McHugh dan Krochta (1994) menambahkan bahwa ketebalan film yang semakin meningkat $(<0.25 \mathrm{~mm}$ ) maka kemampuan penahannya akan semakin baik, sehingga umur simpan produk yang dikemas dalam film semakin panjang. Ketebalan film yang dihasilkan pada penelitian ini lebih tipis dibandingkan dengan penelitian mengenai edible film yang lainnya dengan menggunakan bahan yang berbeda, seperti ketebalan yang diperoleh pada penelitian Mustapa et. al. (2017), dimana bahan yang digunakan yakni pati ubi jalar kuning dengan kitosan dan gliserol, ketebalan film yang dihasilkan sekitar 0.16-0.20 mm, penelitian ini juga mendapatkan ketebalan lebih tipis dari penelitian yang dilakukan oleh Rohman (2016), dimana bahan yang digunkan yakni glutaraldehida dengan kitosan dan CMC, ketebalan film yang dihasilkan sekitar $0.3-0.21 \mathrm{~mm}$.

\section{B. Daya Serap Film}

Uji serap atau ketahanan air merupakan salah satu uji yang dilakukan untuk mengetahui tingkat ketahanan edible film terhadap serap air, pengujian ini dilakukan guna untuk melihat persen serap yang dimiliki oleh film. Pengujian ini dilakukan untuk melihat kemampuan plastik dalam melindungi produk dari air (Lazuardi dan Edi, 2013). Pengujian daya serap air penting dilakukan karena edible film yang baik adalah edible film yang mampu melindungi produk dari air, sehingga nantinya air akan diserap oleh film. Pada pengujian daya serap ini menggunakan metode yang telah dilakukan oleh Kasmawati (2018) yaitu edible film dipotong dengan ukuran 3x3 lalu ditimbang sebagai 
berat awal, setelah itu direndam dalam aquadest selama satu menit dan ditimbang kembali sebagai berat akhir. Nilai persen daya serap film dapat dilihat pada Gambar 2.

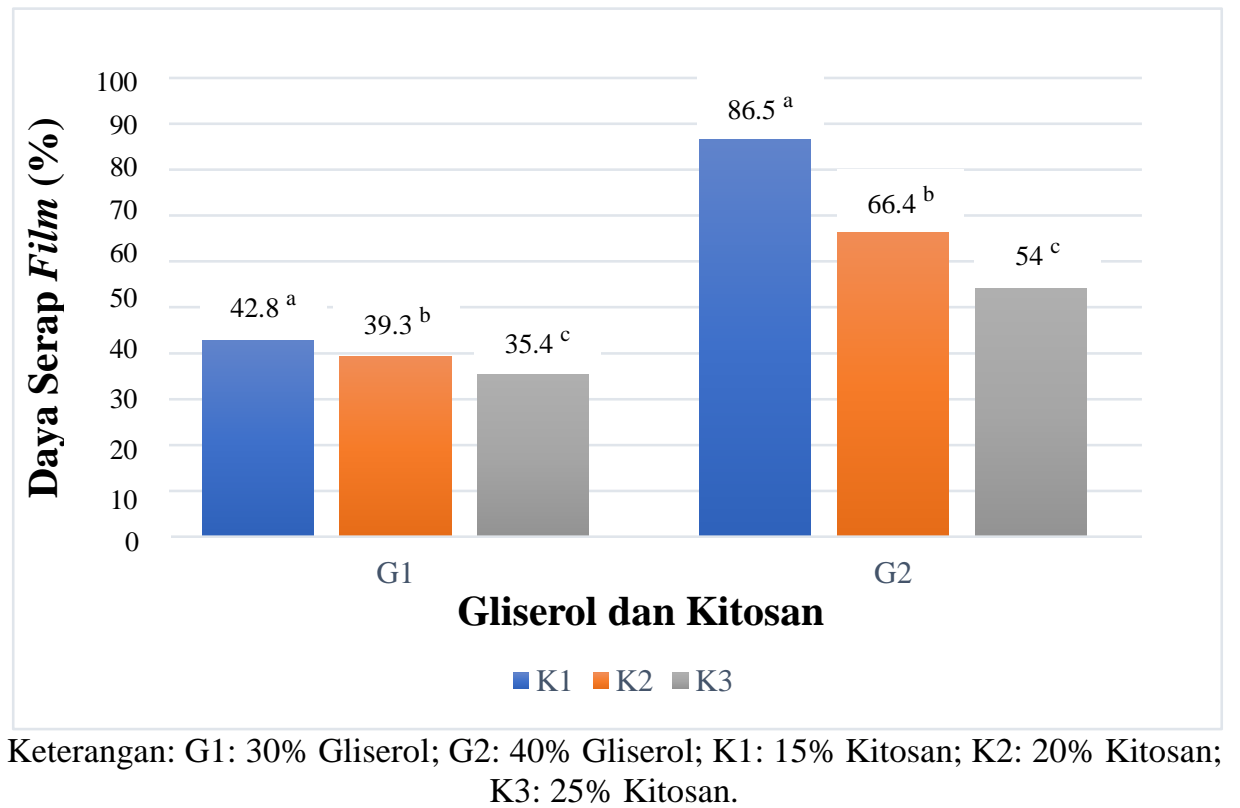

Gambar 2. Daya Serap Edible Film

Berdasarkan Gambar 2 dapat dilihat bahwasanya semakin tinggi konsentrasi gliserol yang ditambahkan maka akan semakin besar persentase daya serap yang dihasilkan, semakin besar persentase daya serap yang dihasilkan maka ketahanan terhadap air nya akan semakin mengecil (Kasmawati, 2018). Terlihat pada penambahan 30\% gliserol didapatkan hasil persentase daya serap sebesar 42.8\%, 39.3\%, 35.4\%, sedangkan penambahan $40 \%$ gliserol mendapatkan hasil persentase daya serap sebesar $86.5 \%$, $66.4 \%$, dan 54\%. Fenomena ini bisa terjadi karena sifat ketahanan air suatu molekul berhubungan dengan sifat dasar komposisi molekul penyusunnya. Bahan pati jagung yang digunakan dalam penelitian ini memiliki sifat hidrofilik, yaitu menyukai air. Penambahan gliserol juga menambah sifat hidrofilik film yang dibuat (Darni, 2010). Fenomena ini juga relevan dengan penelitian yang dilakukan oleh Kasnawati (2018), dalam penelitiannya disebutkan bahwa semakin besar konsentrasi gliserol yang ditambahkan makan akan semakin memperkecil ketahanan nya terhadap air. Indriani (2014) menyatakan bahwa nilai penyerapan air oleh film semakin meningkat dengan semakin meningkatnya jumlah gliserol yang ditambahkan. Daya serap air edible film akan meningkat seiring dengan penambahan konsentrasi plasticizer yang ditambahkan.

Penambahan kitosan juga berperan pada hasil persentase daya serap ini, semakin banyak konsentrasi kitosan yang ditambahkan makan persentase daya serap yang dihasilkan akan semakin menurun, terlihat pada penambahan 15\% kitosan sebanyak memiliki persentase daya serap sebesar $42.8 \%$ dan $86.5 \%$, penambahan $20 \%$ kitosan memiliki persentase daya serap sebesar $39.3 \%$ dan $66.4 \%$, lalu penambahan $25 \%$ kitosan memiliki persentase daya serap sebesar $35.4 \%$ dan $54 \%$. Hal ini dapat terjadi karena pada penambahan kitosan pada variasi tertentu cenderung meningkatkan ketahanan 
terhadap air. Semakin besar konsentrasi kitosan, ketahanan airnya cenderung meningkat dengan persentase water uptake semakin kecil (Setiani et. al, 2013).

Pada uji daya serap inim gliserol dan kitosan saling berinteraksi satu sama lain, terlihat pada Gambar 2 bahwasanya semakin bertambah konsentrasi gliserol maka persetase daya serapnya semakin tinggi, namun jika dilihat kembali pada penambahan konsentrasi kitosan, semakin banyak konsentrasi kitosan yang ditambahkan maka persentase daya serap akan semakin mengecil dan ketahanan terhadap airnya juga akan semakin membesar, hal ini didasari oleh sifat gliserol yang hidrofilik, dan sifat kitosan yang hidrofobik, oleh karena itu kedua nya saling berinteraksi. Setiani et. al. (2013) menyatakan semakin besar konsentrasi kitosan, ketahanan airnya cenderung meningkat dengan persentase water uptake semakin kecil. Semakin bertambahnya konsentrasi kitosan maka akan memiliki hasil persentase daya serap yang berbeda.

C. Kelarutan Film

Kelarutan merupakan salah satu sifat fisik edible film yang menunjukkan persentase berat kering terlarut setelah direndam dalam air selama 24 jam. Menurut Krisna (2011) kelarutan film sangat ditentukan oleh sumber bahan dasar pembuatan film. Edible film dengan daya larut tinggi menunjukkan film tersebut mudah diurai oleh alam dan dapat dicerna dengan baik jika dikonsumsi. Pada pengujian kelarutan ini menggunakan metode yang telah dilakukan oleh Lismawati (2017), dengan memotong film menjadi berukuran $3 \times 3$ lalu direndam selama 24 jam pada aquades. Nilai persentase kelarutan dapat dilihat pada Gambar 3.

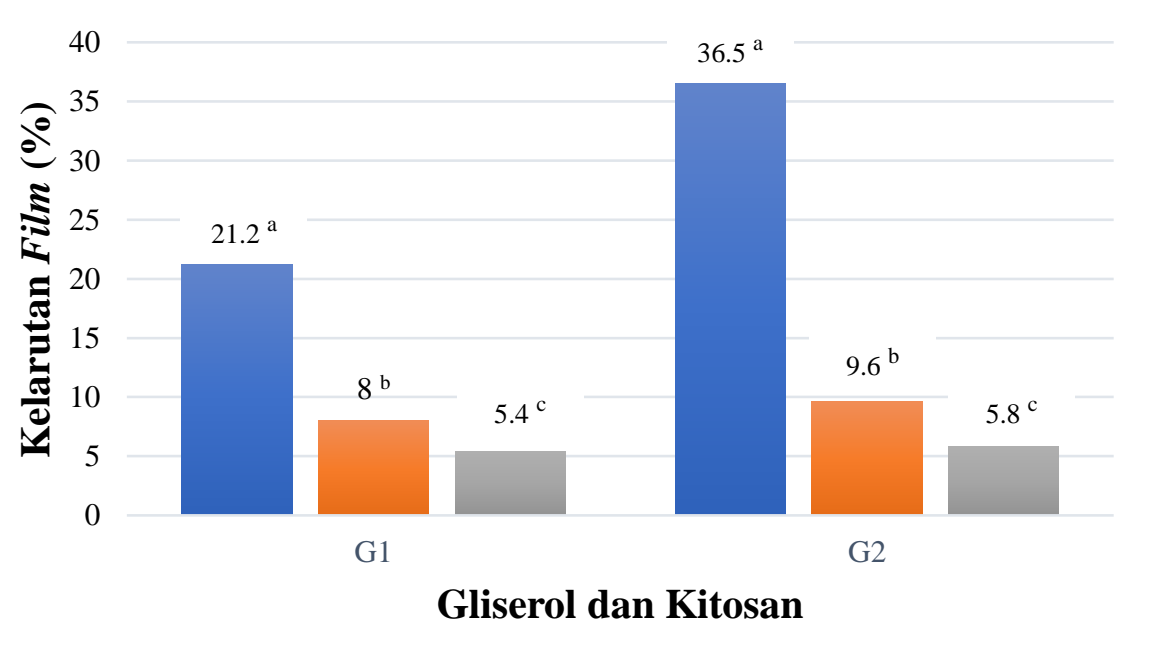

$\square \mathrm{K} 1=\mathrm{K} 2 \mathrm{~K} 3$

Keterangan: G1: 30\% Gliserol; G2: 40\% Gliserol; K1: 15\% Kitosan; K2: 20\% Kitosan; K3: $25 \%$ Kitosan.

Gambar 3. Kelarutan Edible Film

Berdasarkan Gambar 3 dapat dilihat bahwa semakin banyak penambahan gliserol maka kelarutan akan semakin meningkata, terlihat pada penambahan $30 \%$ gliserol menghasilkan kelarutan sebesar $21.2 \%$, $8 \%$ dan 5.4\%, dan pada penambahan $40 \%$ gliserol menghasilkan kelarutan sebesar 36.5\%, 9.6\%, dan 5.8\%. Kelarutan sebuah film 
bergantung pada karakteristik bahan bahan dasar yang digunakan, pati jagung sebagai bahan dasar untuk pembuatan edible film ini bersifat hidrofilik, dan apabila direndam dalam air dengan kurun waktu yang lama akan dengan mudah dilarutkan. Gliserol yang ditambahkan juga memiliki sifat hidrofilik, sehingga gliserol mampu menambah sifat kelarutan dari edible film itu sendiri, semakin tinggi sifat hidrofilik suatu bahan maka akan semakin menambah sifat kelarutannya. Semakin banyak penambahan gliserol maka akan semakin menambah sifat kelarutan film, hal ini sesuai dengan pendapat Lismawati (2017), bahwa peningkatan konsentrasi gliserol akan semakin meningkatkan kelarutan edible film.

Hasil kelarutan pada penelitian ini cenderung lebih rendah dibandingkan dengan hasil penelitian Lismawati (2017) yang mendapatkan kelarutan sebesar 19\%-34\% dengan bahan baku pati kentang, dan hasil penelitian Krisna (2011) yang mendapatkan kelarutan sebesar $14.46 \%-21.06 \%$ dengan bahan dasar pati kacang merah. Hasil pada penelitian ini bisa lebih kecil dari pada penelitian sebelumnya karena memiliki pengaruh dari penambahan konsentrasi kitosan, hal ini terjadi karena kitosan bersifat hidrofobik, sehingga kelarutan film yang dihasilkan memiliki nilai kelarutan yang sangat rendah, hal ini sesuai dengan pendapat Irawan (2010) yang mengatakan sifat kitosan dapat disamakan dengan sifat polimer kationik sehingga kitosan tidak larut dalam air atau larutan alkali pada $\mathrm{pH}$ diatas 6.5. Kitosan larut dengan cepat dalam asam organik cair, seperti asam formiat, asam asetat, asam sitrat dan asam mineral lain kecuali sulfur. Hal ini berarti kitosan tidak mudah larut di air karena sifat hidrofobiknya, sehingga kitosan mempengaruhi karakristik kelarutan yang dihasilkan oleh film ini. Hasil kelarutan pada penelitian ini dapat dilihat untuk membuktikan bahwa kitosan berpengaruh pada nilai 5kelarutan, yang mana pada penambahan $15 \%$ kitosan didapatkan nilai kelarutan sebesar $21.2 \%$ dan $36.5 \%$, pada penambahan $20 \%$ kitosan didapatkan nilai kelarutan sebesar $8 \%$ dan $9.6 \%$, sedangkan pada penambahan $25 \%$ kitosan didapatkan nilai kelarutan yang paling rendah yakni $5.4 \%$ dan $5.8 \%$.

Fenomena ini relevan dengan penelitian pembuatan biodegradable film dari pati biji nangka dengan penambahan kitosan yang dilakukan oleh Hidayah (2015), dimana semakin banyak konsentrasi kitosan yang ditambahkan akan semakin mempengaruhi kelarutan film. Selain itu penelitian studi karakteristik fisik dan mekanik edible film pati ubi jalar ungu dengan penambahan kitosan yang dilakukan oleh Ekariski et. al. (2017) juga relevan pada hasil penelitian ini, dimana semakin banyak konsentrasi kitosan yang ditambahkan maka akan mempengaruhi kelarutan suatu film. Jumlah kitosan yang ditambahkan akan mempengaruhi jumlah komponen terlarut dalam larutan edible film, semakin tinggi komponen terlarutnya maka kelarutannya akan semakin rendah (Derajat, et. al, 2015).

D. Degradasi Film

Degradasi film di lingkungan dapat dipengaruhi oleh beberapa faktor pendukung seperti fisik, biologis dan kimiawi (Hidayah, 2015). Pengujian degradasi ini mengikuti metode yang telah dilakukan oleh Handayani (2015) yaitu dengan merendam film pada 
EM4 selama 15 hari, dan dihitung susut bobotnya per tiga hari. Proses biodegradasi pada biodegradable film di dalam tanah terdiri dua tahapan. Tahap pertama yaitu degradasi kimia melalui proses oksidasi molekul sehingga menghasilkan film dengan berat molekul rendah. Tahap kedua yaitu serangan mikroorganisme (bakteri, jamur dan alga) dan aktifitas enzim (Zulferiyenni et. al, 2014). Nilai persen degradsi film dapat dilihat pada Gambar 4.

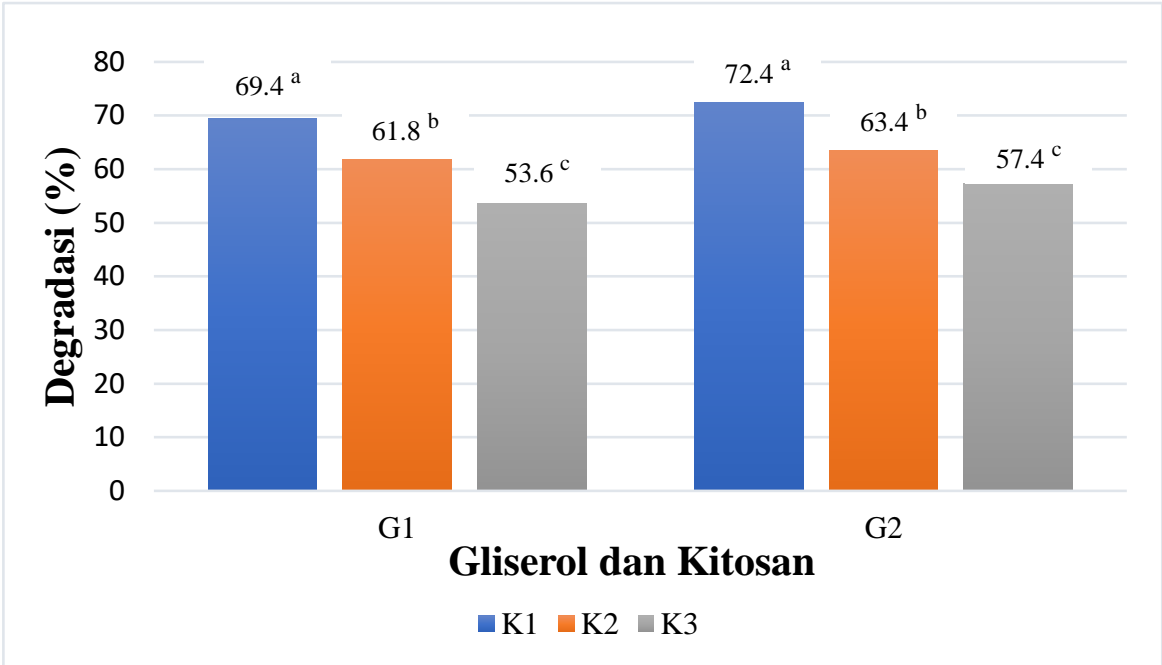

Keterangan: G1: 30\% Gliserol; G2: 40\% Gliserol; K1: 15\% Kitosan; K2: 20\% Kitosan; K3: $25 \%$ Kitosan

Gambar 4. Degradasi Edible Film

Berdasarkan Gambar 4 dapat dilihat bahwa semakin banyak gliserol yang ditambahkan maka nilai persentase film yang terdegradasi semakin besar, terlihat pada penambahan $30 \%$ gliserol mendapatkan nilai degradasi film sebesar $69.4 \%$, 61.8\%, dan $53.6 \%$, sedangkan pada penambahan $40 \%$ gliserol mendapatkan nilai degradasi film sebesar $72.4 \%$, 63.4\%, dan 57.4\%, Hal tersebut dapat terjadi karena sifat biodegradable yang dimiliki oleh film dengan bahan baku dari selulosa maupun pati mudah teruraikan (Tan et al. 2016), ditambah dengan sifat gliserol yang hidrofilik yang dapat meningkatkan kemampuan dalam menyerap air sehingga lebih mudah diuraikan oleh mikroba. Menurut Anggarini (2013) degradasi sebuah film itu berkaitan dengan sifat serap airnya, semakin banyak kandungan air suatu material maka semakin mudah material tersebut untuk terdegradasi. Air merupakan media tumbuh bagi sebagian besar mikroba dan bakteri. Selain karena sifat dari komponen-komponen penyusun yang memang mudah didegradasi secara alami, penambahan gliserol juga berperan dalam tingkat kelarutan dan degradasi fulm.

Pada penelitian ini kitosan juga sangat berperan terhadap persen degradasi film, hal ini terjadi karena kitosan bersifat hidrofobik dan memiliki kandungan antimikroba. Semakin banyak konsentrasi kitosan yang ditambahkan maka persentase degradasi film akan semakin menurun (Hidayah, 2015). Penambahan 15\% kitosan memberikan persentase degradasi sebesar $69.4 \%$ dan $72.4 \%$, diikuti dengan penambahan $20 \%$ kitosan memberikan persentase degradasi sebesar $61.8 \%$ dan $63.4 \%$, dan pada penambahan $25 \%$ kitosan memberikan 
persentase degradasi sebesar 53.6\% dan 57.4\%. Hal ini juga serupa dengan hasil penelitian yang dilakukan oleh Hidayah (2015) bahwa semakin banyak konsentrasi kitosan yang ditambahkan maka akan menurunkan persen degradasi film.

\section{KESIMPULAN}

Gliserol dan kitosan berpengaruh pada ketebalan, daya serap, kelarutan dan degradasi edible film yang dihasilkan. Semakin banyak konsentrasi kitosan dan gliserol yang ditambahkan maka ketebalan film yang dihasilkan akan semakin meningkat (ketebalan berkisar antara 0.06-0.14 mm). Sementara itu semakin banyak konsentrasi gliserol yang dihasilkan maka persentase daya serap film akan semakin besar, namun seiring bertambahnya konsentrasi kitosan yang ditambahkan akan semakin memperkecil persentase daya serap film. Selain itu semakin banyak konsentrasi gliserol yang dihasilkan maka persentase kelarutan film semakin besar, namun seiring bertambahnya konsentrasi kitosan yang ditambahkan akan semakin memperkecil persentase kelarutan yang dihasilkan. Semakin banyak konsentrasi gliserol yang dihasilkan maka persentase degradasi semakin besar, namun seiring bertambahnya konsentrasi kitosan yang ditambahkan akan semakin memperkecil persen degradasi film.

\section{DAFTAR PUSTAKA}

Anggarini, D. Hidayat, N. Febrianto, M., Arie. 2016. Pemanfaatan Pati Ganyong Sebagai Bahan Baku Edible film dan Aplikasinya pada Penyimpanan Buah Apel Anna (Malus sylvestris). Jurnal Teknologi dan Manajemen Agroindustri Volume 5 Nomor 1: 1-8

Anggarini, F. 2013. Aplikasi Plasticizer Gliserol pada Pembuatan Plastik Biodegradable dari Biji Nangka. Skripsi. Universitas Negeri Semarang. 102 hal.

Anggraeni, Y. Sulistiawati, F. Astria, N. Dwi. 2016. Pengaruh Plasticizer Gliserol dan Sorbitol terhadap Karakteristik Film Penutup Luka Kitosan-Tripolifosfat yang Mengandung Asiatikosida. Jurnal Ilmu Kefarmasian Indonesia, hlm. 128-134.

Derajat Z. N., Gede S. M., Sri S., dan Endang S., 2015. Karakteristik Dan Sifat Biodegradasi Edible Film Dari Kulit Pisang Nangka Dengan Penambahan Kitosan Dan Plasticizer Gliserol. Prosiding Seminar Nasional Teknik Kimia.

Ekariski, D. Basito. Yudhistira, B. 2017. Studi Karakteristik Fisik Dan Mekanik Edible Film Pati Ubi Jalar Ungu Dengan Penambahan Kitosan. Jurnal Teknologi Hasil Pertanian. Vol 10. No 2

Handayani, Astuti, P., Wijayanti Hesmita. 2015. Pembuatan Film Plastik Biodegradable Dari Limbah Biji Durian (Durio zibethinus murr). Jurnal Bahan Alam Terbarukan. JBAT 4 (1) 21-26.

Hidayah, I., Betty, Damajanti, N., Puspawiningtyas E. 2015. Pembuatan Biodegradable Film Dari Pati Biji Nangka Dengan Penambahan Kitosan. Prosiding Seminar Nasional Teknik Kimia “Kejuangan' Pengembangan Teknologi Kimia Untuk Pengolahan Sumber Daya Alam Indonesia. Yogyakarta. 
Kasmawati. 2018. Karakteristik Edible Film Pati Jagung (Zea mays L.) Dengan Penambahan Gliserol Dan Ekstrak Temu Putih (Curcuma zedoaria). Skripsi. Jurusan Kimia Fakultas Sains dan Teknologi UIN Alauddin Makassar. 88 hal.

Krisna, D.A. Dimas. 2011. Pengaruh Regelatinasi dan Modifikasi Hidrotermal Terhadap Sifat Fisik Pada Pembuatan Edible Film Dari Pati Kacang Merah (Vigna angularis sp.). Tesis. Jurusan Mejister Teknik Kimia Universitas Diponegoro. Semarang. 154 hal.

Kusumawati, H.D., dan Putri, D.R., Widya. 2013. Karakteristik fisik dan kimia Edible Film pati jagung yang diikorporasi dengan perasan temu hitam. Jurnal pangan dan agroindustry 1 , No. 1 .

Lazuardi, G., P dan Edi, C. 2013. Pembuatan dan Karakteristik Bioplastik Berbahan Dasar Kitosan dan Pati Singkong dengan Plasticizer Gliserol. UNESCA Journal of Chemistry 2, no. 3: h. 161-166.

Lismawati. 2017. Pengaruh Penambahan Plasticizer Gliserol Terhadap Karakteristik Edible Film Pati Kentang (Solanum tuberosum L.). Skripsi. Jurusan Kimia Fakultas Sains dan Teknologi UIN Alauddin Makassar. 97 hal.

McHugh, T. R dan J. M. Krochta. 1994. Dispersed Phase Particlesize Effects On Water Vapor Permeability Of Wheyprotein-Beeswax Edible Emulsion Films. Journal Food Process Pres, Vol. 18:173-188.

Murni, S. Sri, N. Wahyu, P. 2013. Pembuatan Edible Film dari Tepung Jagung (Zea mays L.) Dan Kitosan. Jurnal Pengembangan Teknologi Kimia Untuk Pengelohan Sumber Daya Alam Indonesia 17, No. 1 hal. 1-9.

Mustapa, R, Restuhadi F. Efendi, R. 2017. Pemanfaatan Kitosan Sebagai Bahan Dasar Pembuatan Edible Film Dari Pati Ubi Jalar Kuning. JOM FAPERTA Vol. 4 No. 2.

Ningsih, S. H. 2015. Pengaruh Plasticizer Gliserol Terhadap Karakteristik Edible Film Campuran Whey Dan Agar. Skripsi. Fakultas Peternakan Universitas Hasanuddin Makassar. 98 hal.

Rosalina, V. 2015. Kitosan Sebagai Bahan Dasar Pembuatan Edible Film Dengan Penambahan Pati Ubi Kayu (Manihot esculenta Crantz). Skripsi. Fakultas Pertanian. Universitas Riau. Pekanbaru. 97 hal.

Setiani W. Sudiarti T. Rahmidar L. 2013. Preparasi Dan Karakterisasi Edible Film Dari Poliblend Pati Sukun- Kitosa. Jurnal Valensi Vol. 3 No. 2, (100-109).

Skurtys, O., C. Acevedo, F. Pedreschi, J. Enrione, F. Osorio dan J. M. Aguilera. 2009. Food Hydrocolloid Edible Films and Coatings. Depertment of Food Science and Technology. University Santiago de Chille, Chile.

Winarti, A, Christina, E. 2012. Teknologi Produksi Dan Aplikasi Pengemas Edible Antimikroba Berbasis Pati, Jurnal Litbang Pert 31, No. 3.

Zulferiyenni, Marniza, Sari, E. N. 2014. Pengaruh Konsentrasi Gliserol dan Tapioka Terhadap Karakteristik Biodegradabel Film Berbasis Ampas Rumput Laut, Jurnal Teknologi dan Industri Hasil Pertanian 19, No.3. 